\title{
Distribution of Aggregatibacter actinomycetemcomitans in deep caries lesions
}

\author{
Irena Kuzmanović Radman¹, Aleksandra Đeri', Adriana Arbutina², Jelena Milašin³, Ljiljana \\ Sabljić Amidžić ${ }^{4}$ \\ 'Department of Dental Diseases, Faculty of Medicine, Study program of Dentistry, University of Banja Luka, Banja Luka, \\ Republic of Srpska, Bosnia and Herzegovina; \\ ${ }^{2}$ Department of Orthodontics, Faculty of Medicine, Study program of Dentistry, University of Banja Luka, Banja Luka, \\ Republic of Srpska, Bosnia and Herzegovina; \\ ${ }^{3}$ University of Belgrade, Faculty of Dentistry, Belgrade, Serbia; \\ ${ }^{4}$ Institute for Clinical Pathology UCCRS
}

\begin{abstract}
SUMMARY
Introduction Deep caries is a reversible process where caries lesion has affected bigger part of dentin and only thin layer of softened dentin that separates lesion from the pulp is remained. The objective of this study was to identify and determine serotypes of Aggregatibacter actinomycetemcomitans in teeth with deep caries lesions at the beginning of their treatment.

Material and methods Clinical research included 29 patients of both genders, aged 16 to 40 and 45 permanent teeth with diagnosed deep caries lesions based on medical history, clinical and radiographic examination. After cavity preparation and removal of softened dentin, microbiological swab was taken from the bottom of the cavity. Swabs were disposed in special sterile micro tubes and stored at the temperature of $-80^{\circ} \mathrm{C}$ until serotyping was done (determination of serotypes of A. actinomycetemcomitans bacterium).

Results In one of the 3 samples two serotypes of A. actinomycetemcomitans (b and c) were identified which is relatively rare finding, while in the second and third sample serotypes (a) and serotype (b) was identified, respectively.

Conclusion In the three samples the 3 serotypes were found ( $a, b$ and $c$ ) and one of the samples was carrying even two different serotypes, which is a rare phenomenon. For more serious epidemiological study of A. Actinomycetemcomitans serotypes at the population level incomparably larger starting material is necessary, at least few hundred of samples. Keywords: deep caries lesions; Aggregatibacter actinomycetemcomitans; serotypes; PCR
\end{abstract}

\section{INTRODUCTION}

Dental caries is a chronic complex bacterial infection that results in milligram loss of minerals from infected tooth. Some authors have defined caries as a disease of hard dental tissues (enamel, dentin and cementum) with characteristic processes of demineralization and remineralisation. Deep caries can be classified as clinically visible lesion in dentin characterized by close topographic relation to the pulp, followed by weakening of the sidewalls due to the progression of caries both in width and depth $[1,2]$.

One of the factors affecting the occurrence of caries is dental plaque that represents adhered deposits of bacteria and their products and it exists on every surface of teeth. Dental plaque contains pyogenic bacteria such as Porphyromonas gingivalis, Prevotella intermedia and $\mathrm{Ag}$ gregatibacter actynomycetemcomitans [3]. According to the new classification based on phylogenetic similarity, A. actynomycetemcomitans was in 2006 grouped together with Haemophilus aphrophilus and H. paraphrophilus in the new Aggregatibacter genus. A. actynomycetemcomitans was the first time described in 1912 by Klinger as coccobacillary bacteria isolated together with Actinomyces from actinomycotic lesions of man and it was therefore originally grouped into the Actinomyces genus.

A. actynomycetemcomitans is a non-motile, slowgrowing, capnophilic Gram-negative coccobacilus. It grows slowly at $37^{\circ} \mathrm{C}$, both aerobically and anaerobically. Five stereotypic groups of A. actinomycetemcomitans were classified based on surface polysaccharide, where serotypes a, b and $\mathrm{c}$ are the most prevalent in the oral cavity. A particular clone of serotype b shows enhanced leukotoxic activity. It is predominantly associated with the cases of localized aggressive periodontitis, while the serotype c is usually found in healthy subjects [4-7].

Takahashi et al. demonstrated in an animal model that SPA serotype $b$ has an accentuated ability to stimulate interleukin-1 release from macrophages. The latest data based on molecular genetic analysis indicated significant divergent evolutions of genomes of bacteria serotype a in relation to serotypes $\mathrm{b} / \mathrm{c}$, and differences in genomes implied accentuated phenotypic differences [8]. Pajukanta et al. showed that the response of A. Actynomycetemcomitans to antimicrobials can vary depending on the serotype [9]. 
Table 1. PCR conditions

Tabela 1. Uslovi PCR-a

\begin{tabular}{|c|c|c|c|c|}
\hline $\begin{array}{l}\text { Initial denaturation } \\
\text { Inicijalna denaturacija }\end{array}$ & \multicolumn{3}{|c|}{$\begin{array}{l}35 \text { cycles } \\
35 \text { ciklusa }\end{array}$} & $\begin{array}{c}\text { Final elongation } \\
\text { Finalna elongacija }\end{array}$ \\
\hline \multirow{3}{*}{$3 \mathrm{~min}}$. & \multicolumn{3}{|c|}{$\begin{array}{l}3 \text { steps } \\
3 \text { koraka }\end{array}$} & \multirow{3}{*}{$7 \mathrm{~min}}$. \\
\hline & $\begin{array}{l}\text { Denaturation } \\
\text { Denaturacija }\end{array}$ & $\begin{array}{l}\text { Hybridization } \\
\text { Hibridizacija }\end{array}$ & $\begin{array}{l}\text { Elongation } \\
\text { Elongacija }\end{array}$ & \\
\hline & $15 \mathrm{sec}$. & $30 \mathrm{sec}$. & $1 \mathrm{~min}$. & \\
\hline
\end{tabular}

It is assumed that patients are usually infected with one serotype that is usually maintained over time, i.e. indicates stability [10]. However, more recent research based on molecular genetic testing and not on serological tests, indicated that serotype changes are possible over time. In the study of van der Reijden et al. performed on the population of Indonesian island Java, after 8 years (time interval of the study) there was a change noticed in the prevalence of serotypes at the population level [11]. Among the people who were tested at the beginning and at the end of the study, after 8 years $58 \%$ of them had the same bacterial serotypes, and $42 \%$ of them had other serotypes. They also reported rare cases of multiple serotype infections, around $10 \%$ while during the 8 years of research multiple infections increased from $12 \%$ to $17 \%$ [12].

Another characteristic of A. actynomycetemcomitans is that distribution of serotypes significantly fluctuates depending on geographic region of analysed population as well as periodontal status of teeth. Thus, for example, in the USA, in patients with localized juvenile periodontitis the serotype $b$ is more common than serotypes $a$ and $c$. The situation is similar in Finland population where serotype $\mathrm{b}$ dominates among the patients with periodontal disease, whereas serotype $\mathrm{c}$ is more commonly found among patients with no periodontal disease. In Japanese population, serotypes $\mathrm{a}, \mathrm{c}$ and e were the most common [13].

The aim of this study was to determine and identify serotypes of Aggregatibacter actynomycetemcomitans in teeth with deep caries lesions at the beginning of deep caries treatment.

\section{MATERIAL AND METHODS}

The clinical study was conducted on 45 permanent teeth of patients, aged 16 to 40. Different morphology groups of permanent teeth with deep caries lesions were included in the study. Deep lesions considered dental caries followed by sensitivity to thermal stimuli, affecting more than $3 / 4$ of the tooth crowns with lots of softened dentin. After cavity preparations and removal of softened dentin, the swab was taken from the bottom of the cavity. Taken swabs were disposed in special sterile micro tubes and stored at the temperature of $-80^{\circ} \mathrm{C}$ until serotyping was performed (determination of serotypes of A. actinomycetemcomitans).

The samples were tested at the Institute for Human Genetics, Faculty of Dentistry, University of Belgrade using the multiplex PCR method that enables simultaneous amplification of various gene sequences using multiple pairs of primers. Familiar sequences of primers were used for PCR reactions. Serotyping of A. actynomycetemcomi- tans was also based on the multiplex PCR reaction that included the use of five pairs of primers specific for $a, b, c$, $\mathrm{d}$ and e serotypes of this microorganism, as well as highly specific amplification conditions that are appropriate for all oligonucleotide primers.

The length of products of gene amplification for certain serotypes, with upper pairs of primers were as follows: serotype a: 428 bp, serotype b: 258 bp, serotype c: 559 bp, serotype d: 690 bp and serotype e: $211 \mathrm{bp}$. Reactions were conducted in the total volume of 25 microliters.

PCR conditions are given in the Table 1.

\section{RESULTS}

Oligonucleotide primers specific for the group of genes involved in the biosynthesis of bacterial serotype-specific polysaccharide antigens were designed to be able to identify five main serotypes of A. actynomycetemcomitans (a, $\mathrm{b}, \mathrm{c}, \mathrm{d}$ and e) by using the multiplex PCR. In laboratory conditions, multiplex PCR optimization has proven to be technically demanding and that is why it was possible to serotypically define only a small percentage of samples. A serotype was conditionally established after a number of repeated attempts in only 3 samples. The interesting fact is that two serotypes (b and c) were found in one of the 3 samples, which is relatively rare finding. Figure 1 shows that gel was given after one attempt of serotyping where only one out of 10 samples showed the corresponding strips (10b sample). In the samples \# 18 and \# 23 arrows represent strips that do not correspond to any known serotype and which could be the PCR artefacts.

One of repeated serotyping successfully identified serotypes in 2 more samples: 7c (serotype a) and 6 (serotype c). During repeated multiplex PCR reaction, a nonspecific strip that was present in the first experiment was now lost in the sample 23 (Figure 2).

\section{DISCUSSION}

A. actynomycetemcomitans, ie its serotype $\mathrm{c}$, is a part of normal flora of the oral cavity in healthy patients. This bacterium can also be pathogen because it has significant virulence factors (one of them is adhesion) that enable colonisation of bacteria and intensify its destructive potential in oral diseases [14]. Serotyping of bacteria is a suitable typization method for epidemiological studies. Primarily it is easy to perform and more sensitive compared to other methods that require additional equipment and are more costly [15]. 


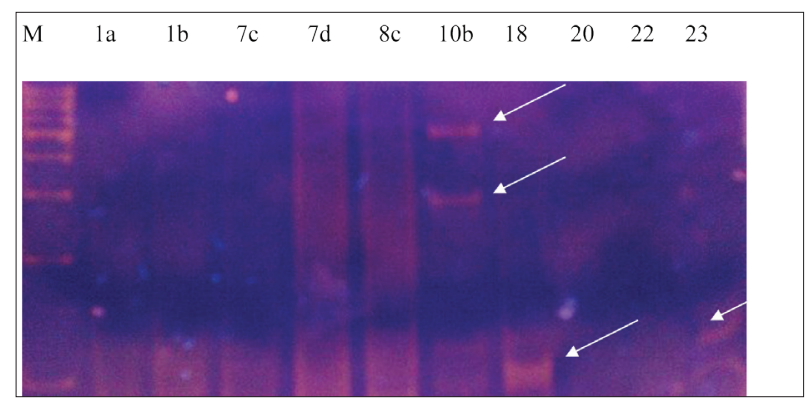

Figure 1. Multiplex PCR-based serotyping. In the sample 10b the arrows correspond to the familiar serotypes: b (298 bp) and c (559 bp). Strips in the samples no. 18 and no. 23 were nonspecific. $M$ indicates molecular scale.

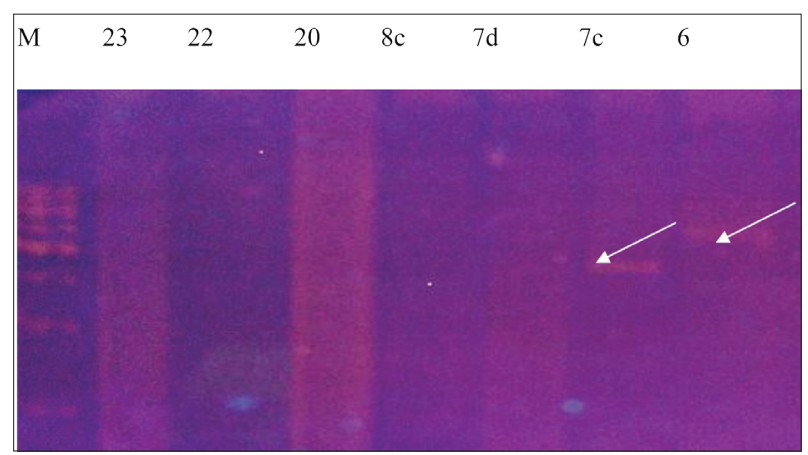

Figure 2. Repeated series of serotyping. In the samples $7 c$ and 6 , the expected length of strips was found, $428 \mathrm{bp}$ for the serotype a and 559 bp for the serotype c. $M$ indicates molecular scale.

Slika 2. U uzorcima 7c i 6 uočavaju se trake očekivanih dužina 428 bp za a, i 559 bp za c serotip. M označava molekulsku lestvicu.

Dental caries is multibacterial disease but serotyping is the only method to determine certain serotypes of bacteria that play role in aetiology. Number of studies has shown that certain bacteria detected in dental plaque are closely associated with the occurrence of caries while large caries lesions often communicate with subgingival biofilm bacteria. Streptococcus mutans and Aggregatibacter actynomycetemcomitans are oral pathogenic bacteria associated with caries and periodontal disease. Psoter et al. (2011) aimed to determine colonization of these two microorganisms in dental plaque of adolescents from rural areas of Haiti by using two different methods of polymerase chain reactions (PCR): Standard PCR and Quantitative real-time PCR (qPCR). This study included 152 plaque samples from 104 patients aged 12 to 19 years. Total genomic DNA of these bacteria was isolated from the samples while dental caries or periodontal changes were found in all subjects during clinical examination. The results showed moderate to high prevalence of $S$. $m u$ tans and A. actinomicetemcomitans in all samples [16-20].

A large number of teeth affected with deep caries in both, upper and lower jaw (regardless the morphological group of teeth) could primarily be explained with socioeconomic and health conditions, not only in war but also in the post-war period in our region. Certainly the most important factor is the level of health care that does not meet basic health needs of the population. Also, difficult social situation and struggle for pure existence often put dental health as second priority. More frequent occurrence of deep caries on the upper and lower molars could be explained by the fact that occlusal surfaces of these teeth is susceptible to caries, due to their morphology and the existence of fissures and cusps. It is also well-known fact that nutrition, use of fluorides and oral hygiene have dominant influence on the occurrence of caries.

During clinical examination in this study, poor oral hygiene was noticed among the respondents. Sofrata et al. (2008) tested the antibacterial effect of Miswak sticks for oral hygiene against bacteria involved in the occurrence of periodontal disease and caries including A. actynomycetemcomitans. The Miswak sticks were standardized by size and weight (0.07 and $0.14 \mathrm{~g}$ ) and they were tested against S. mutans, Lactobacillus acidophilus, A. actynomycetemcomitans, Porphiromonas gingivalis and Haemophilus influenzae. The inhibitory effect of the pieces of Miswak sticks embedded in the agar plate was most pronounced on P. gingivalis, A. actynomycetemcomitans, $H$. influenzae and less on S. mutans and L. acidophilus [21].

The literature indicates that it is impossible to determine the serotype in 3 to $8 \%$ of samples of A. Actynomycetemcomitans [22]. Unfortunately, this percentage was significantly higher in our study. We tried to overcome technical problems in many ways by changing the number of experimental parameters but we got unsatisfactory results. Multiplex PCR was performed with different amounts of starting material and different duration of particular steps of reaction. Also, the number of cycles was modified $(25,30,35)$ as well as $\mathrm{MgCl}_{2}$ concentrations and hybridization temperature. However, even after all the effort and repeated attempts the success of serotyping was moderate. We were able to determine A. Actynomycetemcomitans serotypes in only $21 \%$ of the samples.

Numerous studies have come to conclusion that $A$. actynomycetemcomitans is most frequently associated with periodontal diseases [23]. The study of Cortelli et al. (2005) showed the presence of $A$. actynomycetemcomitans in $41.6 \%$ of the subjects with chronic periodontal disease and $72 \%$ of subjects with acute periodontal disease [24]. Tinoco et al. also found A. actynomycetemcomitans in $80 \%$ of young patients with periodontal disease and suggested that the presence of this bacterium in the oral cavity may serve as an indicator of risk for future tests of acute periodontal disease [25].

Based on research of deep caries lesions Simon-Soro and Mira found diverse ecosystem made of a large number of bacteria affecting the spreading of caries lesions. The results showed that $S$. mutans was present in a small percentage and that other bacteria including A. actynomycetemcomitans affect spreading of caries lesions [26].

\section{CONCLUSION}

Given the small initial number of teeth, relatively small percentage of samples positive for A. actynomycetemcomitans and finally, poor achievement of the multiplex reaction of serotyping, it is impossible to talk about the prevalence of certain serotypes in our population. In the 3 samples three serotypes of A. actinomycetemcomitans (a, $\mathrm{b}$ and c) were identified and two different serotypes were 
identified in one of the samples that is a rare phenomenon. For more serious epidemiological study of serotypes of A. Actinomycetemcomitans at the population level and their relation to the formation of dental caries an incomparably larger starting material is necessary, at least a few hundred of samples.

\section{REFERENCES}

1. Al-Hiyasat AS, Barrieshi-Nusair KM, Al-Omari MA. The radiographic outcomes of direct pulp-capping procedures performed by dental students: a retrospective study. J Am Dent Assoc. 2006; 137(12):1699-705. [DOI: 10.14219/jada.archive.2006.0116] [PMID: 17138715]

2. Ahmad S. Al-Hiyasat, Kefah M, Barrieshi-Nusair. The radiographic outcomes of direct pulp-capping procedures performed by dental students: a retrospective study. I Am Dent Assoc. 2006; 137(12):1699-705. [DOI: 10.14219/jada.archive.2006.0116] [PMID: 17138715]

3. Arora A, Scott JA, Bhole S, Do L, Schwarz E, Blinkhorn AS. Early childhood feeding practices and dental caries in preschool children: a multi-centre birth cohort study. BMC Public Health. 2011; 11:28. [DOI: 10.1186/1471-2458-11-28] [PMID: 21223601]

4. Nørskov-Lauritsen N, Kilian M. Reclassification of Actinobacillus actinomycetemcomitans, Haemophilus aphrophilus, Haemophilus paraphrophilus and Haemophilus segnis as Aggregatibacter actinomycetemcomitans gen. nov., comb. nov., Aggregatibacter aphrophilus comb. nov. and Aggregatibacter segnis comb. nov., and emended description of Aggregatibacter aphrophilus to include $\mathrm{V}$ factor-dependent and $\mathrm{V}$ factor-independent isolates. Int J Syst Evol Microbiol. 2006; 56(9):2135-46. [DOl: 10.1099/ijs.0.642070] [PMID: 16957111]

5. Taylor LS, Selwyn DRL. Aggregatibacter actinomycetemcomitans (Actinobacillus actinomycetemcomitans). Available from: www. antimicrobe.org/new/b72.asp

6. Zambon J), Slots J, Genco RJ. Serology of oral Actinobacillus actinomycetemcomitans and serotype distribution in human periodontal disease. Infect Immun. 1983; 41(1):19-27. [PMID: 6407997]

7. Haubek D, Johansson A. Pathogenicity of the highly leukotoxic JP2 clone of Aggregatibacter actinomycetemcomitans and its geographic dissemination and role in aggressive periodontitis. J Oral Microbiol. Published online 2014. [DOI: 10.3402/jom.v6.23980] [PMID: 25206940]

8. Takahashi T, Nishihara T, Ishihara Y, Amano K, Shibuya N, Moro I, et al. Murine macrophage interleukin-1 release by capsularlike serotype-specific polysaccharaide antigens of Actinobacillus actinomycetemcomitans. Infect Immun. 1991; 59(1):18-23. [PMID: 1987032]

9. Pajukanta R, Asikainen S, Saarela M, Alaluusua S, Jousimies-Somer $H$. In vitro antimicrobial susceptibility of different serotypes of Actinobacillus actinomycetemcomitans. Scand I Dent Res. 1993; 101:299-303. [PMID: 1329617]

10. Asikainen S, Lai CH, Alaluusua S, Slots J. Distribution of Actinobacillus actinomycetemcomitans serotypes in periodontal health and disease. Oral Microbiol Immunol. 1991; 6(2):115-8. [DOI: 10.1111/j.1399-302X.1991.tb00462.x] [PMID: 1945486]

11. Van der Reijden WA, Bosch-Tijhof C], van der Velden U, van Winkelhoff AJ. Java project on periodontal diseases: serotype distribution of Aggregatibacter actinomycetemcomitans and serotype dynamics over an 8-year period. J Clin Periodontol. 2008;
35(6):487-92. [DOI: 10.1111/j.1600-051X.2008.01218.x] [PMID: 18422698]

12. Suzuki N, Nakano Y, Yoshida Y, Ikeda D, Koga T. Identification of Actinobacillus actinomycetemcomitans serotypes by Multiplex PCR. J Clin Microbiol. 2001; 39(5): 2002-5. [DOI: 10.1128/ JCM.39.5.2002-2005.2001] [PMID: 11326035]

13. Kouidhi B, Zmantar T, Mahdouani K, Hentati H, Bakhrouf A. Antibiotic resistance and adhesion properties of oral Enterococci associated to dental caries. BMC Microbiology. 2011; 29: 11:155. [DOI: 10.1186/1471-2180-11-155] [PMID: 21714920]

14. Musić L, Puhar I. Aggregatibacter actynomycetemcomitans osobna iskaznica parodontopatogena. Sonda. 2014; 15(28):45-8.

15. Stanković Nedeljković N, Kocić B, Tiodorović B, Branković S, Mladenović Antić S. Serotipizacija i analiza vrsta proizvedenih pigmenata kliničkih izolata Pseudomonas aeruginosa. Vojnosanitetski pregled. 2011; 68(11):923-9. [DOI: 10.2298/VSP1111923] [PMID: 22191308]

16. Loesche WJ. Role of Streptococcus mutans in human dental decay. Microbiol Rev. 1986; 50:353-80. [PMID: 3540569]

17. Van Houte J. Role of microorganisms in caries etiology. J Dent Res. 1994; 73:672-81. [PMID: 8163737]

18. Psoter WJ, Ge Y, Russell SL, Chen Z, Katz RV, Jean-Charles G, et al. PCR detection of Streptococcus mutans and Aggregatibacter actinomycetemcomitans in dental plaque samples from Haitian adolescents. Clin Oral Investig. 2011; 15(4):461-9. [DOI: 10.1007/ s00784-010-0413-y] [PMID: 20446101]

19. Henderson B, Nair SP, Ward JM, Wilson M. Molecular pathogenicity of the oral opportunistic pathogen Actinobacillus actinomycetemcomitans. Annu Rev Microbial. 2003; 57:29-55. [DOl: 10.1146/annurev.micro.57.030502.090908] [PMID: 14527274]

20. Fine DH, Markowitz K, Furgang D, Fairlie K, Ferrandiz J, Nasri C, et al. Aggregatibacter actinomycetemcomitans and its relationship to initiation of localized aggressive periodontitis: longitudinal cohort study of initially healthy adolescents. J Clin Microbial. 2007; 45:3859-69. [DOI: 10.1128/JCM.00653-07] [PMID: 17942658]

21. Sofrata AH, Claesson RL, Lingström PK, Gustafsson AK. Strong antibacterial effect of Miswak against oral microorganisms associated with periodontitis and caries. J Periodont. 2008; 79(8):1474-9. [DOI: 10.1902/jop.2008.070506] [PMID: 18672998]

22. Rylev M, Kilian M. Prevalence and distribution of principal periodontal pathogens worldwide. J Clin Periodontal. 2008; 35:346-61. [DOl: 10.1111/j.1600-051X.2008.01280.x.] [PMID: 18724862]

23. Kittichotirat W, Bumgarner R, Chen C. Markedly different genome arrangements between serotype a strains and serotypes b or $\mathrm{c}$ strains of Aggregatibacter actinomycetemcomitans. BMC Genomics. 2010; 8;11:489. [DOI: 10.1111/j.1600-051X.2008.01280.x.] [PMID: 20825670]

24. Tinoco EM, Beldi MI, Loureiro CA, Lana M, Campedelli F, Tinoco NM, et al. Localized juvenile periodontitis and Actinobacillus actinomycetemcomitans in a Brazilian population. Eur J Oral Sci. 1997; 105(1):9-14. [DOI: 10.1007/s00784-010-0413-y] [PMID: 9085023]

25. Cortelli JR, Cortelli SC, Jordan S, Haraszthy VT, Zambon JJ. Prevalence of periodontal pathogens in Brazilians with aggressive or chronic periodontitis. J Clin Periodontal. 2005; 32(8):860-6. [DOI: 10.1590/S1517-83822006000400036] [PMID: 15998269]

26. Simon-Soro A, Mira A. Solving the etiology of dental caries. Trends Microbiol. 2015; 23(2):76-82. [DOI: 10.1016/j.tim.2014.10.010] [PMID: 25435135] 


\title{
Zastupljenost bakterije Aggregatibacter actinomycetemcomitans u dubokim karijesnim lezijama
}

\author{
Irena Kuzmanović Radman', Aleksandra Đeri', Adriana Arbutina², Jelena Milašin², Ljiljana Sabljić Amidžić ${ }^{4}$ \\ ${ }^{1}$ Katedra za bolesti zuba, Medicinski fakultet, Studijski program Stomatologija, Univerzitet u Banjoj Luci, Banja Luka, Republika \\ Srpska, Bosna i Hercegovina; \\ ${ }^{2}$ Katedra za ortopediju vilica, Medicinski fakultet, Studijski program Stomatologija, Univerzitet u Banjoj Luci, Banja Luka, Republika \\ Srpska, Bosna i Hercegovina; \\ ¿Univerzitet u Beogradu, Stomatološki fakultet, Beograd, Srbija; \\ ${ }^{4}$ Zavod za kliničku patologiju UKCRS
}

\begin{abstract}
KRATAK SADRŽAJ
Uvod Duboki karijes je reverzibilni proces kod kojeg je karijesna lezija zahvatila veći deo dentina i samo tanak sloj razmekšalog dentina razdvaja leziju od pulpe.

Cilj ovog rada je bio da se na početku terapije utvrde i odrede serotipovi bakterije Aggregatibacter actynomycetemcomitans kod zuba sa dubokim karijesnim lezijama.

Materijal i metod rada Kliničko ispitivanje je obuhvatalo 29 pacijenata, oba pola, uzrasta od 16 do 40 godina i 45 stalnih zuba kod kojih je na osnovu anamneze, kliničkog i radiografskog pregleda dijagnostikovan duboki karijes. Posle preparacije kaviteta i uklanjanja razmekšalog dentina, sa dna kaviteta je uziman bris, odlagan u posebne sterilne mikrotubice i čuvan na temperaturi od $-80^{\circ} \mathrm{C}$ do postupka serotipizacije (utvrđivanja serotipova bakterije Aggregatibacter actynomycetemcomitans) primenom metode multipleks PCR. Rezultati Serotipizacija je registrovana u samo tri uzorka. U jednom od tri uzorka identifikovana su dva serotipa A. actynomycetemcomitans - b i c, što je relativno redak nalaz, dok su u drugom i trećem uzorku identifikovani serotipovi a, odnosno serotip b. Zaključak $U$ tri uzorka nađena su tri serotipa - a, b i c, a jedan od uzoraka je nosio čak dva različita serotipa, što je redak fenomen. Za ozbiljniju epidemiološku studiju serotipova A. Actynomycetemcomitans na nivou populacije neophodan je neuporedivo veći uzorak i to reda veličine nekoliko stotina.
\end{abstract}

Ključne reči: duboka karijesna lezija; Aggregatibacter actinomycetemcomitans; serotipovi PCR

\section{UVOD}

Zubni karijes je hronična kompleksna bakterijska infekcija koja dovodi do miligramskih gubitaka minerala iz zuba koji je zahvaćen infekcijom. Pojedini autori su definisali karijes kao oboljenje tvrdih zubnih tkiva (gleđi, dentina i cementa) koje karakterišu naizmenični procesi demineralizacije i remineralizacije. Duboki karijes predstavlja klinički vidljivu leziju u dentinu i karakterišu je vrlo blizak topografski odnos lezije sa pulpom i oslabljeni bočni zidovi kaviteta usled napredovanja karijesa u širinu i dubinu $[1,2]$.

Jedan od faktora koji utiče na nastanak karijesa je dentalni plak, koji predstavlja adherirani depozit bakterija i njihovih produkata, koji se formira na svim površinama zuba. U zubnom plaku je moguće detektovati brojne bakterije, ali i prisustvo piogenih bakterija kao što su Porphyromonas gingivalis, Prevotella intermedia i Aggregatibacter actynomycetemcomitans [3].

Aggregatibacter actynomycetemcomitans je bakterija koja je po novoj klasifikaciji svrstana sa bakterijama Haemophilus aphrophilus i H. paraphrophilus u novi Aggregatibacter rod. Klinger je 1912. godine ovu bakteriju prvi put opisao kao kokobacil koji je bio izolovan zajedno s bakterijama roda Actinomyces iz aktinomikotičkih lezija čoveka. To je nepokretni, spororastući, kapnofilni gram-negativni kokobacil koji raste sporo na temperaturi od $37^{\circ} \mathrm{C}$, u aerobnoj ili anaerobnoj sredini. Klasifikovano je pet sero skupina $A$. actinomycetemcomitans na osnovu površinskih polisaharida, od čega su serotipovi a, b i c najčešće prisutni u usnoj šupljini. Specifični klon b serotipa pokazuje povećanu leukotoksičnu aktivnost i predominantno se povezuje sa slučajevima lokaliziranog agresivnog parodontitisa, dok se serotip c najčešće nalazi kod zdravih osoba [4-7].
Takahashi i saradnici su pokazali na animalnom modelu da SPA serotipa b imaju izraženiju sposobnost da stimulišu oslobađanje interleukina-1 iz makrofaga od SPA sojeva a i c.Najnoviji podaci zasnovani na molekularno-genetičkim analizama ukazuju na značajnu divergentnu evoluciju genoma bakterija serotipa a u odnosu na serotipove $\mathrm{b} / \mathrm{c}$, a razlike u genomima podrazumjevaju i izražene fenotipske razlike [8].

Pajukanta i saradnici su pokazali da je odgovor A. actynomycetemcomitans na antimikrobna sredstva podložan varijacijama u zavisnosti od serotipa [9].

Smatra se takođe da su pacijenti najčešće inficirani jednim serotipom koji se po pravilu održava tokom vremena, jer je vrlo stabilan [10]. Međutim, novija istraživanja, zasnovana na molekularno genetičkim testovima, ukazuju na to da su moguće serotipske promene tokom vremena. U studiji Van der Reijdena i saradnika [11] na stanovništvu indonežanskog ostrva Java, nakon osam godina (vremenski interval studije) došlo je do promene prevalence serotipova na populacionom nivou. Od osoba koje su ispitane na početku i na kraju studije (nakon osam godina) 58\% je zadržalo iste bakterijske serotipove, a kod $42 \%$ su se pojavili drugi. Zanimljiva je i činjenica da su uočeni retki slučajevi infekcija multiplim serotipovima (oko 10\%), dok je u pomenutoj studiji holandskih naučnika tokom osam godina istraživanja zapažen porast multiplih infekcija, sa 12 na $17 \%$ [12].

Još jedna karakteristika A. actynomycetemcomitans je da serotipovi pokazuju prilične varijacije u distribuciji u zavisnosti od geografskog regiona analiziranih populacija, odnosno od parodontalnog stanja ispitivanih grupa. Tako npr. u SAD kod pacijenata sa lokalizovanim juvenilnim periodontitisom češći je serotip b od serotipova a i c. Slično je i u Finskoj populaciji, gde serotip b dominira među pacijentima sa parodontopatijama, 
dok se serotip c često sreće kod osoba koje su parodontalno zdrave. U japanskoj populaciji kod obolelih su najučestaliji serotipovi a, c i e [13].

Cilj ovog rada je bio da se na početku terapije utvrde i odrede serotipovi bakterije Aggregatibacter actynomycetemcomitans kod zuba sa dubokim karijesnim lezijama.

\section{MATERIJAL I METOD RADA}

Kliničko istraživanje je sprovedeno na 45 stalnih zuba pacijenata dobi od 16 do 40 godina. U istraživanje su bili uključeni stalni zubi različitih morfoloških grupa sa dubokim karijesnim lezijama. Duboka lezija je podrazumevala karijes zuba kod pacijenata koji je praćen osetljivošću na termičke nadražaje i koji je zahvatio više od $3 / 4$ krunice zuba sa dosta razmekšalog dentina. Posle preparacije kaviteta i uklanjanja razmekšalog dentina, sa dna kaviteta je uzet bris koji je odlagan u posebne sterilne mikrotubice i čuvan na temperaturi od $-80^{\circ} \mathrm{C}$ do serotipizacije (utvrđivanja serotipova bakterije Aggregatibacter actynomycetemcomitans).

Uzorci su ispitani na Institutu za humanu genetiku Stomatološkog fakulteta Univerziteta u Beogradu, primenom metode multipleks PCR, koja omogućava simultanu amplifikaciju različitih genskih sekvenci uz korišćenje više parova prajmera. Za izvođenje PCR reakcije korišćene su poznate sekvence prajmera. Serotipizacija Aggregatibacter actynomycetemcomitans je takođe bila zasnovana na multipleks PCR reakciji koja je podrazumevala korišćenje pet parova prajmera specifičnih za serotipove $a, b$, c, d i e ovog mikroorganizma, kao i usko specifične uslove amplifikacije koji odgovaraju svim oligonukleotidnim prajmerima.

Produkti amplifikacije gena za pojedine serotipove, sa gornjim parovima prajmera, bili su sledećih dužina: serotip a - 428 bp, serotip b - 258 bp, serotip c - 559 bp, serotip d - 690 bp i serotip e - $211 \mathrm{bp}$.

Reakcije su rađene u ukupnoj zapremini od 25 mikrolitara, a uslovi PCR-a dati su u tabeli 1.

\section{REZULTATI}

Oligonukleotidni prajmeri specifični za grupu gena uključenih u biosintezu bakterijskih serotip-specifičnih polisaharidnih antigena dizajnirani su tako da mogu da identifikuju pet glavnih serotipova bakterije A. actynomycetemcomitansa (a, b, c, d i e) i to koristeći multipleks PCR. U laboratorijskim uslovima optimizacija multipleks PCR se pokazala tehnički zahtevnom te je mali procenat uzoraka mogao da bude serotipski definisan. U svega tri uzorka, i to iz više ponovljenih pokušaja, uslovno je ustanovljen serotip. Zanimljivo je to što su u jednom od ta tri uzorka uočena čak dva serotipa (b i c), što je relativno redak nalaz. Na slici 1 dat je gel nakon jednog od pokušaja serotipizacije, gde je od 10 uzoraka samo jedan pokazao odgovarajuće trake (uzorak 10b). U uzorcima broj 18 i 23 strelicama su označene trake koje ne odgovaraju poznatim serotipovima, a koje bi mogle biti artefakti PCR-a.

Jedan od ponovljenih pokušaja serotipizacije uspeo je da identifikuje serotipove u još dva uzorka: 7c i 6 . U uzorku 7c serotip je a, a u uzorku 6 serotip je c. Tokom ponovljene reakcije multipleks PCR-a izgubila se nespecifična traka u uzorku 23 koja je bila prisutna u prvom eksperimentu (Slika 2).

\section{DISKUSIJA}

Bakterija A. actynomycetemcomitans, odnosno njen serotip c, predstavlja deo normalne flore usne šupljine kod zdravih pacijenata. Ova bakterija može biti i patogena jer poseduje značajan faktor virulencije - adheziju, koja omogućava kolonizaciju bakterija, čime se pojačava njen destruktivni potencijal u oralnim oboljenjima [14].

Serotipizacija bakterija je adekvatna tipizaciona metoda za epidemiološka ispitivanja jer ima mnoge prednosti u odnosu na druge metode ispitivanja bakterija. Prvenstveno je jednostavnija za izvođenje i osetljivija u odnosu na druge metode koje zahtevaju dodatnu opremu i finansijski su zahtevnije [15].

Mnoge bakterije učestvuju u nastanku karijesa pa je i serotipizacija kao postupak određivanja pojedinih bakterija vrlo značajna u razjašnjavanju etiologije. Veliki broj istraživanja je pokazao da su pojedine bakterije koje su detektovane u dentalnom plaku usko povezane sa nastankom karijesa, a velike karijesne lezije često komuniciraju sa bakterijama subgingivalnog biofilma. Streptococcus mutans i Aggregatibacter actynomycetemcomitans su oralne patogene bakterije koje se dovode u vezu i sa karijesom i sa parodontopatijom. Upravo zbog toga su Psoter i njegovi saradnici (2011) imali za cilj da utvrde kolonizaciju ova dva mikroorganizama u dentalnom plaku adolescenata iz ruralne oblasti Haitija pomoću dve različite metode lančane reakcije polimeraze (PCR), tj. standardne PCR i kvantitativne real-time PCR (kPCR). Ova studija je obuhvatala 152 uzorka plaka od 104 pacijenta starosne dobi od 12 do 19 godina. Ukupna genomska DNK ovih bakterija izolovana je iz uzoraka, a kod svih ispitanika je pronađen karijes ili parodontološka promena tokom kliničkog pregleda. Rezultati su pokazali umerenu do visoke prevalence $S$. mutans i A. actinomicetemcomitans u uzorcima [16-20].

Veliki broj zuba zahvaćenih dubokim karijesom i u gornjoj i u donjoj vilici (bez obzira na morfološku grupu zuba) mogao bi se objasniti pre svega socijalnoekonomskim i zdravstvenim uslovima ne samo u ratu nego i u posleratnom periodu na ovim prostorima. Ipak, najvažniji faktor bi mogao biti stepen zdravstvene zaštite koji ne zadovoljava osnovne zdravstvene potrebe stanovništva. Takođe, teška socijalna situacija u borbi za čistu egzistenciju često stavlja zdravlje zuba u drugi plan. Češća pojava dubokog karijesa na molarima gornje i donje vilice mogla bi se objasniti činjenicom da je okluzalna površina ovih zuba prijemčiva za karijes, zbog njihove morfologije odnosno postojanja fisura i kvržica. Takođe, poznato je da dominantan uticaj na pojavu karijesa imaju ishrana, primena fluorida i oralna higijena.

U ovoj studiji, tokom kliničkog pregleda, takođe je uočena lošija oralna higijena kod svih ispitanika. Sofrata i saradnici (2008) ispitivali su antibakterijski efekat Misvak štapića za održavanje oralne higijene na bakterije koje učestvuju u nastanku parodontopatije i karijesa, među kojima i na Aggregatibacter actynomycetemcomitans. Dejstvo Misvak štapića je nakon njihove standardizacije po veličini i težini $(0,07$ i $0,14 \mathrm{~g})$ proveravano na Streptococcus mutans, Lactobacillus acidophilus, Aggregatibacter actynomycetemcomitans (ranije Actinobacillus actinomicetemcomitans), Porphiromonas gingivalis, i na Haemophilus influenzae. Komadi Misvak štapića su ugrađeni u agar podloge te je uočen njihov najveći inhibitorni efekat kod $P$. gingivalis, $A$. actynomycetemcomitans, $H$. influenzae, a znatno manji efekat na S. mutans i L. acidophilus [21]. 
U literaturi se navodi podatak da je za 3 do $8 \%$ uzoraka $A$. actynomycetemcomitans nemoguće odrediti serotip [22]. Nažalost, u našoj studiji taj procenat je neuporedivo veći. Pokušaj da se na razne načine prevaziđu tehnički problemi, menjanjem eksperimentalnih parametara, nije dalo rezultate. Multipleks PCR je rađen sa različitom količinom polaznog materijala i u različitom trajanju pojedinih koraka reakcije. Takođe, menjan je i broj ciklusa $(25,30,35)$, a modifikovane su i koncentracije $\mathrm{MgCl}_{2}$, kao i temperature hibridizacije. Međutim, i posle svih napora i ponovljenih pokušaja, uspeh u serotipizaciji je bio veoma skroman. Kod samo 21\% uzoraka određen je serotip bakterija A. actynomycetemcomitans. Mnogobrojnim studijama se došlo do zaključka da je A. actynomycetemcomitans ipak najčešće povezan sa parodontološkim oboljenjima [23].

Cortelli i saradnici su u svom istraživanju (2005) utvrdili zastupljenost A. actynomycetemcomitans kod 41,6\% ispitanika sa hroničnom parodontopatijom i kod $72 \%$ pacijenata sa akutnom parodontopatijom [24].

Takođe, Tinoco i saradnici su pronašli bakteriju A. actynomycetemcomitans kod $80 \%$ uzoraka mladih ispitanika sa parodontopatijom i predložili da zastupljenost ove bakterije u usnoj šupljini može poslužiti kao indikator rizika za buduća ispitivanja akutne parodontopatije [25].

Simon-Soro i Mira su na osnovu istraživanja dubokih karijesnih lezija otkrili raznovrstan ekosistem, sačinjen od velikog broja bakterija, koji utiče na širenje karijesne lezije. Rezultati su ukazali na to da je S. mutans bio zastupljen u manjem procentu, a da veliki broj bakterija, a samim tim i $A$. actynomycetemcomitans ima uticaj na širenje karijesne lezije [26].

\section{ZAKLJUČAK}

S obzirom na mali uzorak zuba i relativno mali procenat pozitivnih uzoraka $A$. actynomycetemcomitans, odnosno slabiji uspeh multipleks reakcije serotipizacije, teško je govoriti o prevalenciji pojedinih serotipova u našoj populaciji. $U$ tri uzorka nađena su tri serotipa ( $a, b$ i c), a jedan od uzoraka je nosio čak dva različita serotipa, što je redak fenomen. Za ozbiljniju epidemiološku studiju serotipova $A$. actynomycetemcomitans na nivou populacije i njihovu vezu za nastankom karijesa neophodan je neuporedivo veći uzorak, i to reda veličine nekoliko stotina. 